\title{
VERTAISTOIMINNAN MUODOT JA MERKITYS PÄIHDE- JA MIELENTERVEYSJÄRJESTÖISSÄ
}

\section{Johdanto}

Vertaistoiminnan voi sanoa alkaneen Yhdysvalloissa vuonna 1935 perustetuista Anonyymien Alkoholistien AA-ryhmistä (Arminen 1998; Laimio \&t Karnell 2010, 9), vaikka vertaistukea on hyödynnetty skitsofreniaa sairastavien hoidossa jo 1920-luvulla (Davidson ym. 1999, 167). Suomessa A-klinikoiden asiakkaiden 1960-luvulla aloittamaa A-kiltatoimintaa voidaan pitää sosiaalihuollon asiakastoiminnan edelläkävijänä (Rajala 2008). Mielenterveyskuntoutujien vertaistukeen alettiin kiinnittää huomiota vasta 1990-luvun lama-aikana (Lehtinen 1997, 39). Toiminta alkoi Mielenterveyden keskusliiton oma-apuprojektista (Vuorinen \& Helasti 1997, 8) ja klubitaloliikkeestä.

Vertaistuki on usein yhdistysten organisoimaa toimintaa, jolloin ne tarjoavat tilat sekä koulutusta ja tukea vertaisille. Toiseksi vertaistuki voi olla kansalaislähtöistä ja omaehtoista toimintaa ilman taustayhteisöä. Kolmanneksi se voi olla osa julkisen sektorin tai yhdistyksen tuottamia palveluja, jolloin vertaistuki kuuluu asiakkaan hoito- tai kuntoutusprosessiin. Vertaistukea toteutetaan erilaisissa ympäristöissä: kahdenkeskisenä tukena, toiminnallisissa ryhmissä, avoimissa kohtaamispaikoissa, verkkovertaistukena ja ryhmätoimintana vertaisryhmissä, joissa ohjaajana voi olla vertainen, ammattilainen tai vertais - ammattilaistyöpari. (Huuskonen 2015.) Tämän kaltaista vertaistukea voi kutsua henkilökohtaiseksi auttamiseksi tai tukemiseksi. Vertaistuki voi toteutua myös välillisenä, jolloin vertainen tukee toisia kuntoutujia tai toipujia osallistumalla yhdistyksen toiminnan tai palvelujärjestelmän kehittämiseen. (Rissanen 2015.)

\section{Tutkimuksen käsitteet ja teoreettinen tausta}

Laajasti määriteltynä vertaistuella voidaan tarkoittaa kaikkea inhimillistä vuorovaikutusta ja omasta elämäntilanteesta keskustelemista (Nylund 1996, 194). Tässä artikkelissa käsitämme vertaistuen organisoiduksi toiminnaksi, jossa samanlaisissa tilanteissa olevat tai samantyyppisistä ongelmista kärsivät jakavat kokemuksiaan (Nylund 1996, 194; Arminen 1998). Vertaistuen taustalla on ihmisten sosiaalisuus, tarve vuorovaikutukseen ja yhteisöön kuulumiseen (Laimio \&t Karnell 2010, 9).

Vertaistuen ominaisuuksia ovat kyky ymmärtää toisia kokemuksellisuuden kautta (Arminen 1998, 11; Hietala 2013, 294), erityinen yhteys ihmisten välillä (Rissanen 2015) sekä vastavuoroinen tukeminen (Koskisuu \& Narumo 2004, 19; Muurinaho 2001, 16). Vertaistuen tarve liitetään tilanteisiin, joissa ystävien, sukulaisten tai ammattiauttajien antama tuki ja apu eivät riitä, koska heiltä puuttuu omakohtainen kokemus (Nylund 1999, 116).

Potilas- ja vammaisjärjestöissä vertaistuen arvoja ovat tasavertaisuus, tasa-arvoisuus, molemminpuolisuus, omaehtoisuus, aktiivisuus ja vapaaehtoisuus (Campbell 1996, 220; Nylund 1996, 193-194; Hokkanen 2014, 25). Arvot konkretisoituvat vertaistoiminnan lähtökohdissa, kuten ajatuksessa siitä, että jokai- 
sella on jotain annettavaa. Ryhmäläiset antavat ja saavat tukea samaan aikaan eli he auttavat yhtä aikaa itseään sekä toisia. (Mikkonen 1996, 225; Nylund 1996, 193-194, 204; Arminen 1998, 203-205; Kangas 2003; Koskisuu \&t Narumo 2004, 21.) Toinen vertaistuen lähtökohdista liittyy omaehtoisuuteen: ainoastaan yksilö itse voi muuttaa elämänsä suuntaa ja ajattelutapoja (Mikkonen 1996, 225; Nylund 1996, 193-194, 204; Arminen 1998, 203-205; Kangas 2003; Koskisuu \&t Narumo 2004, 21). Vertaisryhmissä ei myöskään arvoteta eikä arvostella itseä eikä toisia (Kulmala 2004, 237-238).

Vertaisryhmät ovat merkittäviä psyykkisesti sairastuneille, koska sairastumisesta seuraa usein sosiaalisia menetyksiä, eristäytymistä, yksinäisyyttä, häpeää, syyllisyyttä, ympäristön kielteisiä asenteita sekä heikentyneitä mahdollisuuksia kuulua yhteisöihin (Hietala-Paalasmaa \&t Vuorela 2004, 30; Savukoski 2008; Mikkonen 2009, 149). Sama stigma ja sosiaaliset menetykset koskevat myös ihmisiä, joilla on päihdeongelma. Vertaistuen avulla on mahdollista vastata näihin menetyksiin. Näyttää tosin siltä, että vertaistuen piiriin hakeutuvat todennäköisemmin ne, joilla jo on sosiaalista pääomaa (Hokkanen 2014, 26).

Vertaisuus on mielenterveysyhdistysten toiminnan ydin, aatteellinen perusta ja keskeinen arvo (Hietala-Paalasmaa \&t Vuorela 2004, 35-36; Kaskela ym. 2014). Alueellisen terveysja hyvinvointitutkimuksen (ATH) aineistoon perustuvan tutkimuksen (Kaskela ym. 2014) mukaan mielenterveyshoidon kynnyksellä ${ }^{1}$ olleiden ihmisten järjestöosallistumisessa korostuu halu saada apua ja vertaistukea omaan elämäntilanteeseen ja auttaa muita sekä tarve kuulua ryhmään. He osallistuivat järjestötoimintaan yhtä usein kuin muu väestö. Tarve osallistua mielenterveysyhdistysten toimintaan noussee myös palveluiden riittämättömyydestä ja palvelujärjestelmän pirstaleisuudesta. Mieli 2009 -ohjelman väliarvioinnin mukaan mielenterveyspalvelujärjestelmä on vaikeasti hahmotettava ja hajanainen (STM 2012). Liisa Hokkanen $(2014,66)$ toteaa tutki- muksessaan mielenterveysjärjestöjen aktiivitoimijoista myös, että kynnys hakea ammattilaisapua mielenterveysongelmiin on korkea, ja vertaistuella täydentynyt lähipiiri on usein ensisijainen avun ja tuen lähde. Päihdehoidon kynnyksellä olevat puolestaan osallistuvat yhdistystoimintaan muuta väestöä harvemmin (Kaskela ym. 2014), ja toimintaan osallistujien määrä on päihdejärjestöissä pienempi kuin muissa sosiaali- ja terveysjärjestöissä (Siltaniemi ym. 2011, 151).

Yksilöiden ja yhteisöjen omaehtoisen avun merkityksen on ennustettu kasvavan, kun vastuuta hyvinvoinnista siirretään julkiselta sektorilta vertaisyhteisöille ja yksilöille. Kehitykseen on viitattu muun muassa tee-se-itse -yhteiskunnan ja vertaistukiyhteiskunnan käsitteillä (esim. Leppo \&t Perälä 2015). Vertaistoiminnalla oli keskeinen rooli myös kansallisessa Mieli 2009 -suunnitelmassa, jonka tavoitteisiin kuului vertaisten ottaminen mukaan mielenterveys- ja päihdetyön suunnitteluun, toteuttamiseen ja arviointiin. Nämä ajankohtaiset keskustelut korostavat tarvetta tutkia yhdistysten organisoiman vertaistoiminnan toteuttamistapoja, mahdollisuuksia ja haasteita.

\section{Aineisto ja menetelmät}

Artikkelissa tarkastelemme päihde- ja mielenterveysyhdistysten vertaistoimintaa sekä organisaation että toimijoiden itsensä näkökulmasta. Tutkimuskysymyksiksi nousivat:

1) Millainen vertaistoiminnan merkitys on päihde- ja mielenterveysjärjestöissä?

2) Mitkä tekijät motivoivat vertaisia osallistumaan vertaistoimintaan?

3) Missä määrin vertaiset kokevat uupumisen ja väsymisen tunteita toimiessaan vertaisina?

4) Millaisia tarpeita ja konkreettisia toimia järjestöissä on vertaisten tukemiseksi?

Tutkimusaineisto on kerätty osana Rahaautomaattiyhdistyksen tukemaa Päihde- ja mielenterveysjärjestöjen tutkimusohjelmaa (MIPA-hanke) (ks. http://www.a-klinikka.fi/ tietopuu/jarjestotutkimusohjelma). MIPA on

${ }^{1}$ Hoidon kynnyksellä olemisen määrittelystä ks. Kaskela ym. 2014, 2 
kymmenen päihde- ja mielenterveysjärjestön (A-Kiltojen liitto ry, EHYT ry, Irti Huumeista ry, Mielenterveyden keskusliitto ry, FinFamiUusimaa ry, Sininauhaliitto, Suomen Mielenterveysseura, Tukikohta ry, A-klinikkasäätiö, Kuntoutussäätiö) sekä Diakonia-ammattikorkeakoulun yhteinen tutkimushanke, jonka puitteissa tuotetaan tietoa muun muassa järjestöjen toiminnasta sekä vertaisuudesta.

Artikkelin aineisto koostuu kahdesta kyselystä. Järjestötoiminnan kysely lähetettiin keväällä 2016 päihde- ja mielenterveyskentällä toimivien paikallisyhdistysten toiminnanjohtajille tai hallituksen puheenjohtajille. Se sisälsi kysymyksiä toiminnan eri osa-alueista, mukaan lukien vertaistoiminta. Kysely lähetettiin 432 paikallisyhdistykselle (227 päihdeyhdistykselle ja 205 mielenterveysyhdistykselle). Vastauksia saatiin 209 paikallisyhdistykseltä (vastausprosentti 48). Aineistosta karsittiin toimijat, jotka eivät harjoita aktiivista järjestötoimintaa tai jotka palauttivat tyhjän kyselylomakkeen. Lopullinen aineisto koostuu 87 päihde- ja 100 mielenterveysyhdistyksestä. Paikallisten päihde- ja mielenterveysyhdistysten tuloksia verrataan toisiinsa. Tuloksia tarkastellaan lisäksi yhdistyksen perustamisvuoden ja toiminta-alueen asukasluvun mukaan. Valtakunnallisten järjestöjen pieni määrä ei mahdollistanut niiden tarkastelua taustamuuttujien mukaan.

Muuttujien jakaumat on esitetty taulukossa 1. Toiminta-alueen asukasluku selvitettiin kysymyksellä "Kuinka paljon asukkaita toimialueellanne on?" (min=300, $\max =630$ 000, $\mathrm{ka}=60998$, med=22 000). Perustamisvuotta kysyttiin seuraavasti: "Minä vuonna yhdistyksenne on perustettu?" ( $\min =1946$, $\max =2112$, $\mathrm{ka}=1990$, med=1993). Vastaajat ilmoittivat itse yhdistyksensä toiminta-alueen asukasluvun ja perustamisvuoden. Yhdistykset jaoteltiin kolmeen yhtä suureen luokkaan yhdistyksen toiminta-alueen asukasluvun ja perustamisvuoden mukaan. Vertaistoiminnan merkitystä kysyttiin kysymyksellä "Millainen merkitys vertaistoiminnalla on yhdistyksessänne?" Vastausvaihtoehdot olivat: $0=$ ei koske yhdistystämme, 1 = pieni merkitys, 2 = kohtalainen merkitys, 3 = suuri merkitys. $(\min =0$,
Taulukko 1. Järjestökyselyssä käytettyjen muuttujien jakaumat.

\begin{tabular}{|ll|}
\hline Vertaistoiminnan merkitys & \\
\hline $\begin{array}{l}\text { ei koske yhdistystä } \\
\text { pieni merkitys } \\
\text { kohtalainen merkitys } \\
\text { suuri merkitys }\end{array}$ & $5 \%(n=8)$ \\
& $6 \%(n=11)$ \\
Toimintapaikkakunnan asukasluku & $22 \%(n=39)$ \\
\hline alle 10000 & $67 \%(n=119)$ \\
\hline $100001-50000$ & $33 \%(n=43)$ \\
yli 50000 & $38 \%(n=50)$ \\
& $29 \%(n=39)$ \\
\hline Yhdistyksen perustamisvuosi & \\
\hline $\begin{array}{l}\text { ennen vuotta 1986 } \\
1986-1999\end{array}$ & $34 \%(n=61)$ \\
2000-luvulla & $42 \%(n=75)$ \\
\hline Vertaistoiminnan muodot & $24 \%(n=44)$ \\
\hline vertaistukiryhmät & \\
toiminnallinen vertaisuus & \\
internet-välitteinen vertaisuus & $59 \%(n=111)$ \\
\hline
\end{tabular}

$\max =3, \mathrm{ka}=2,52$, med=3). Koska valtaosa vastasi "suuri merkitys", yhdistettiin tilastollisten tarkastelujen mahdollistamiseksi muut luokat kuvaamaan vertaistoiminnan pientä merkitystä. Vertaistoiminnan muotoja selvitettiin kysymyksellä "Mitkä seuraavista ovat yhdistyksenne toimintamuotoja?" (vertaistukiryhmät, toiminnallinen vertaisuus, internet-välitteinen vertaisuus).

Täydentävää tietoa kerättiin vertaisille ja työntekijöille kohdistetulla vertaistoiminnan kyselyllä, jossa kartoitettiin toiminnan sisältöä, merkitystä yksilöille ja yhdistyksen toiminnalle, vertaisten roolia sekä uupumisen tuntemuksia. Linkki sähköiseen kyselyyn jaettiin tutkimusohjelmaan kuuluvien yhdistysten yhteyshenkilöiden $(n=10)$ kautta. Vastauksia saatiin 61 työntekijältä ja 77 vertaiselta. Kyselyn vastausprosenttia ei voi arvioida, koska kyseessä ei ole otantatutkimus. Kyselyyn vastaaminen oli vapaaehtoista ja anonyymiä. Osa yhdistyksistä on hyvin pieniä, joten anonymiteetin varmistamiseksi ja vastaamiseen rohkaisemiseksi vastaajilta ei kysytty taustayhdistyksen nimeä. Näin ollen tulosten analysoimisessa ei erotella valtakunnallisten järjestöjen ja paikallisyhdistysten vastauksia. Jatkossa käytämme selkeyden vuoksi käsitettä järjestö. 
Kyselyyn vastanneista vertaisista 76 prosenttia toimi mielenterveysalan järjestöissä, 42 prosenttia päihdealan järjestöissä ja 7 prosenttia omaisjärjestöissä. Työntekijöistä suurin osa (82\%) työskenteli päihdealan järjestöissä, 37 prosenttia mielenterveysalan järjestöissä ja kuusi prosenttia omaisjärjestöissä. Vastausprosentit ovat yli sata, koska vertaiset voivat toimia useassa järjestössä yhtä aikaa ja toisaalta järjestöjen toimialat voivat kattaa eri toimintamuotoja. Päällekkäisyyksien vuoksi päihde- ja mielenterveysjärjestöjen vastauksia ei vertailtu keskenään. Vertaistoiminnan kysely laadittiin yhdessä tutkimusohjelmassa mukana olevien järjestöjen vapaaehtoisista ja vertaisista kootun ryhmän $(n=7)$ kanssa heidän tärkeinä pitämiensä teemojen pohjalta.

Kvantitatiivista aineistoa analysoitiin SPSS-ohjelmistolla käyttämällä korrelaatioita ja ristiintaulukointeja. Prosenttilukujen suuruuserojen tilastollisen merkitsevyyden testaamiseen käytettiin nelikenttien osalta Fisherin eksaktia testiä ja laajempien taulukoiden kohdalla Pearsonin khiin neliö -testiä. Vertaistoiminnan kyselystä analysoitiin lisäksi työntekijöiden ja vertaisten antamia avoimia vastauksia, joilla syvennettiin kvantitatiivisesta aineistosta nousseita teemoja. Avovastaukset teemoiteltiin aiheisiin, jotka toistuivat vastauksissa erilaisissa muodoissa, sekä arvioitiin niiden määrällinen esiintyvyys. Tutkimuksessa yhdistettiin siis kahden eri kyselyn tuottamaa sekä kvantitatiivista että kvalitatiivista aineistoa. Monimenetelmällisyydellä tavoiteltiin laajemman ymmärryksen saavuttamista järjestöjen vertaistoiminnasta kartoittamalla siihen liittyvien ilmiöiden esiintyvyyttä, sisältöjä ja merkityksiä sekä organisaation että toimijoiden itsensä näkökulmasta.

Artikkelin aluksi kartoitamme vertaisuuteen liittyviä toimintamuotoja. Sen jälkeen tarkastelemme vertaistoiminnan merkitystä päihde- ja mielenterveysjärjestöjen toiminnassa yhdistysten johdon, työntekijöiden ja vertaisten näkökulmista. Lopuksi käsittelemme vertaisten uupumista ja tuen tarvetta sekä tukemisen keinoja.

\section{Vertaistoiminnan muodot ja vertaisten tehtävät päihde- ja mielenterveysjärjestöissä}

Järjestökyselyssä kartoitettiin vertaistoiminnan muotoja paikallisyhdistyksissä ja valtakunnallisissa järjestöissä. Tarkastelun kohteina olivat vertaistukiryhmät, toiminnallinen vertaisuus ja internet-välitteinen vertaisuus (taulukko 2).

Vertaistukiryhmiä oli 60 prosentissa aineiston päihde- ja mielenterveysyhdistyksistä, huomattavasti useammin mielenterveysyhdistyksissä (74 \%) kuin päihdeyhdistyksissä (43\%). Toiminnallinen vertaisuus kuului joka toisen yhdistyksen toimintamuotoihin ja internet-välitteistä vertaistukea tarjosi vajaa viidennes paikallisyhdistyksistä. Vertaistoi-

Taulukko 2. Vertaistoiminnan muotojen jakaumat yhdistyksen tai järjestön toimialan, toimintapaikkakunnan asukasluvun ja perustamisvuoden mukaan sekä ryhmien välisten erojen merkitsevyys.

\begin{tabular}{|c|c|c|c|c|}
\hline & \multicolumn{2}{|r|}{ vertaistukiryhmät } & \multicolumn{2}{|c|}{ toiminnallinen vertaisuus } \\
\hline & $\%(n)$ & $\mathrm{p}$ & $\%(n)$ & $p$ \\
\hline päihdeyhdistykset (n=86) & $43 \%(n=37)$ & \multirow{4}{*}{ Fisherin eksakti testi; $p<0,001$} & $56 \%(n=48)$ & \multirow{4}{*}{ Fisherin eksakti testi; $p=0,105$} \\
\hline mielenterveysyhdistykset ( $n=100)$ & $74 \%(n=74)$ & & $46 \%(n=46)$ & \\
\hline valtakunnalliset järjestöt (n=28) & $54 \%(n=15)$ & & $46 \%(n=13)$ & \\
\hline yli 50000 asukasta $(n=39)$ & $77 \%(n=30)$ & & $62 \%(n=24)$ & \\
\hline $10000-50000$ asukasta $(n=50)$ & $42 \%(n=21)$ & \multirow{3}{*}{$X^{2}(2)=11,111 ; p=0,004$} & $48 \%(n=24)$ & \multirow{4}{*}{$X^{2}(2)=1,618 ; p=0,445$} \\
\hline alle 10000 asukasta $(n=42)$ & $52 \%(n=22)$ & & $53 \%(n=23)$ & \\
\hline perustettu 2000-luvulla ( $n=44)$ & $55 \%(n=24)$ & & $48 \%(n=21)$ & \\
\hline perustettu v. $1986-2000(n=74)$ & $61 \%(n=45)$ & \multirow[b]{2}{*}{$X^{2}(2)=1,754 ; p=0,416$} & $44 \%(n=33)$ & \\
\hline perustettu ennen vuotta $1986(n=61)$ & $67 \%(n=41)$ & & $64 \%(n=39)$ & $X^{2}(2)=5,715 ; p=0,057$ \\
\hline
\end{tabular}


minnan muodot erosivat yhdistyksen toiminta-alueen asukasluvun ja perustamisajankohdan mukaan. Yhteydet olivat samansuuntaisia kuin vertaistoiminnan merkityksessä, eli kaikkia toimintamuotoja oli eniten suurilla toiminta-alueilla toimivissa ja ennen vuotta 1986 perustetuissa yhdistyksissä. Erityisesti vertaistukiryhmät ja verkkovertaisuus olivat yleisempiä suurilla toiminta-alueilla. Vaikka virtuaalinen vertaisuus parantaa järjestöjen mahdollisuuksia tavoittaa syrjäseutujen ja pienempien paikkakuntien asukkaita, sen järjestäminen vaatii usein läsnäoloa järjestön toimitiloissa, joten sen keskittyminen suuriin kaupunkeihin lienee luonnollista. Toiminnallista vertaisuutta järjestettiin samoissa määrin riippumatta yhdistyksen toiminta-alueen koosta.

Joka toinen valtakunnallisista järjestöistä tarjosi ryhmätoimintaan ja toiminnallisuuteen perustuvaa vertaisuutta. Virtuaalinen vertaistoiminta kuului joka kolmannen valtakunnallisen järjestön toimintavalikkoon, ja se oli niissä yleisempää kuin paikallisyhdistyksissä.

Vertaistoiminnan muotoja, sisältöä ja vertaisten roolia tarkennettiin vertaisille ja työntekijöille suunnatun kyselyn perusteella. Toimintamuotojen monipuolisuus näkyy seuraavassa työntekijän kuvauksessa vertaisten tehtävistä:

"Osallistuvat koulutusryhmiin, joissa saavat tietoja ja taitoja vertaisena toimimi-

internet-välitteinen vertaisuus $\%(n)$ $\mathrm{p}$

$22 \%(n=19)$

$14 \%(n=14)$

$36 \%(n=10)$

$31 \%(n=12)$

$8 \%(n=4)$

$7 \%(n=3)$

$18 \%(n=8)$

$11 \%(n=8)$

$28 \%(n=17)$
Fisherin eksakti testi; $p=0,101$

$X^{2}(2)=12,066 ; p=0,002$

$X^{2}(2)=6,650 ; p=0,036$ seen. Tekevät itsenäisesti vertaistoimintaa verkostoissaan pääasiallisina muotoina vertaistuki/keskustelu, hoitoon tai palveluihin ohjaus, hoitoon tai palveluihin saattaminen, puhtaiden pistosvälineiden vaihtaminen sekä lomakkeiden täyttämisessä auttaminen (esim. Kela). Muutama vertainen kerrallaan toimii yhdessä hankkeen ryhmässä vertaisohjaajana. Vertaiset ovat myös mukana kouluttamassa. He osallistuvat seminaareihin ja verkostoihin ja ovat hankkeen ohjausryhmässä edustettuina. He osallistuvat kaksi kertaa vuodessa hankkeen väliarviointiin.” (Työntekijä 1.)

Työntekijöiden vastauksissa korostui erityisesti vertaistuen tarjoaminen ja vertaisten ryhmänohjaajarooli, johon kuului esimerkiksi kurssien vetämistä sekä toisten neuvomista ja ohjaamista käsitöissä, askartelussa tai pientuotteiden tekemisessä. Vertaiset toimivat usein konkreettisissa auttamistehtävissä, esimerkiksi saattajina kolmannen sektorin paikkoihin, tukena viranomaisasioinnissa, eläkevalmentajina ja tukikoirakkona. He kävivät myös laulamassa palvelukodeissa, vierailivat asumisyksiköissä ja osallistuivat toimintapäiviin. Lisäksi vertaiset osallistuivat järjestöjen käytännön tehtäviin. He vastasivat kahvion, päivätuvan tai kokoontumistilan toiminnasta, laittoivat ruokaa, siivosivat, avustivat tapahtumissa ja retkillä tai päivittivät verkkosivuja. Toiminnan ja tekemisen ohessa tapahtuva asioiden jakaminen ja tukijana tai kuuntelijana toimiminen tuntui kuitenkin usein vertaisen pääasialliselta tehtävältä.

"Varsinaiseksi tehtäväkseni koen ryhmäläisten tekemisen ilon kokemuksen tukemisen, viihtyisyyden ja tervetulleeksi kokemisen, mahdollisuuden kertoa kuulumisiaan ja vapaaehtoisesti halutessaan jakaa kokemuksiaan mukavan ja rentouttavan tekemisen lomassa." (Vertainen 1.)

Vertaistuki voi olla myös kahdenkeskistä, kuten tukihenkilötoiminta, yksilökeskustelut, vertaisvastaanotot ja vertaistukipuhelimeen vastaaminen. Vertaisia toimi myös erilaisis- 
sa verkkoauttamisen ja -tukemisen tehtävissä. He ylläpitivät esimerkiksi vertaistukiryhmää Facebookissa tai tukivat toisia Skypen välityksellä.

Vertaiset korostivat vastauksissaan työntekijöitä enemmän toimimistaan kouluttamiseen, luennointiin ja paneeleissa esiintymiseen liittyvissä tehtävissä. Tiedottaminen ja julkisuustyö sisälsivät erilaisiin tapahtumiin osallistumista, lehtihaastatteluja, esiintymisiä sähköisissä tietopalveluissa ja Youtubessa. Vertaistoiminta toteutui usein yhteistyössä ammattilaisten kanssa, jolloin he toimivat ammattilaisen työparina ryhmänohjaajina tai osallistuivat yhteistyökokouksiin, kehittämistyöryhmiin sekä suunnittelu- ja ohjausryhmiin. Vertaistuki voi olla lähellä ammatillisia tehtäviä, jolloin vertaiset olivat työsuhteessa hanke- tai päiväkeskustyöntekijöinä. Tiedollisia valmiuksia edellyttivät myös terveysneuvonta, sosiaali- ja palveluohjaus sekä talousja velkaneuvonta. Lisäksi vertaiset olivat usein mukana yhdistyksen hallituksessa puheenjohtajana, sihteerinä tai jäsenenä.

\section{Vertaistuen merkitys päihde- ja mielenterveysjärjestöjen toiminnalle}

Vertaistoiminnalla oli suuri merkitys 67 prosentille aineiston paikallisyhdistyksistä (taulukko 1). Vain kymmenesosalle merkitys oli pieni tai yhdistys ei harjoittanut vertaistoimintaa. Vertaistoiminta koettiin yhtä tärkeäksi niin päihde- kuin mielenterveysyhdistyksissäkin ja valtakunnallisissa järjestöissä lähes yhtä tärkeäksi kuin paikallisyhdistyksissä (taulukko 3).

Vertaistoiminnan merkityksen ja yhdistyksen perustamisvuoden välillä oli khiin neliö -testin mukaan tilastollisesti merkitsevä yhteys ( $p=0,007)$. Vertaisuus koettiin keskeisemmäksi toiminnan painopisteeksi ennen vuotta 1986 perustetuissa yhdistyksissä verrattuna myöhempinä vuosina perustettuihin yhdistyksiin.

Vertaistuen merkitys korostui myös järjestöjen työntekijöiden vastauksissa. He totesivat usein, että toiminta perustuu vertaisuuteen ja vertaisten työpanos on tärkeä:

"Heidän työpanoksensa on korvaamaton. Kaikki yhdistyksen toiminta perustuu vertaistukeen ja yhdessä tekemiseen." (Työntekijä 2.)

Vertaisten ja vertaistuen merkitystä korostettiin asiakastyössä. Työntekijät painottivat vertaisten omakohtaisen kokemuksen merkitystä toisille kuntoutujille. Tämä näkyi erityisesti etsivässä työssä ja palvelujen tuottamisessa. Vertaisten eli entisten asiakkaiden osallistumisen työhön nähtiin lisäävän nykyisten asiakkaiden luottamusta ammattilaisten toimintaa kohtaan ja parantavan toiminnan uskottavuutta. Vertaisten kokemus toipumisesta on uskottavampi ja vakuuttavampi kuin ammattilaisen tietämys.

Taulukko 3. Jakaumat vertaistoiminnan merkityksestä toiminnan painopisteenä yhdistyksen tai järjestön toimialan, toimintapaikkakunnan asukasluvun ja perustamisvuoden mukaan sekä ryhmien välisten erojen merkitsevyys.

\begin{tabular}{|l|c|c|l|}
\hline & $\begin{array}{c}\text { suuri } \\
\text { merkitys }\end{array}$ & $\begin{array}{l}\text { kohtalainen/pieni } \\
\text { merkitys tai ei } \\
\text { koske yhdistystä }\end{array}$ & $\begin{array}{l}\text { erojen tilastollinen } \\
\text { merkitsevyys }\end{array}$ \\
päihdeyhdistykset $(n=80)$ & $73 \%(n=58)$ & $27 \%(n=22)$ & \\
mielenterveysyhdistykset $(n=97)$ & $63 \%(n=61)$ & $37 \%(n=36)$ & Fisherin eksakti testi; $p=0,116$ \\
valtakunnalliset järjestöt $(n=28)$ & $65 \%(n=17)$ & $35 \%(n=11)$ & \\
yli 50000 asukasta $(n=35)$ & $74 \%(n=26)$ & $26 \%(n=9)$ & \\
$10000-50000$ asukasta $(n=47)$ & $70 \%(n=33)$ & $30 \%(n=14)$ & \\
alle 10000 asukasta $(n=42)$ & $57 \%(n=24)$ & $43 \%(n=18)$ & $x^{2}(2)=2,902 ; p=0,234$ \\
perustettu 2000-luvulla $(n=42)$ & $64 \%(n=27)$ & $36 \%(15)$ & \\
perustettu v. 1986-2000 $(n=73)$ & $58 \%(n=42)$ & $43 \%(n=31)$ & \\
perustettu ennen vuotta 1986(n=59) & $83 \%(n=49)$ & $17 \%(n=10)$ & $x^{2}(2)=10,050 ; p=0,007$ \\
\hline
\end{tabular}


"Vertaiset tavoittavat niitä käyttäjiä kaduilta, jotka eivät 'uskalla' syystä tai toisesta tulla itse palveluiden piiriin." (Työntekijä 3.)

Työntekijät liittivät vertaistuen hyödyllisyyden asiakastyöhön, erityisesti vertaisten ja asiakkaiden yhteiseen kieleen sekä päihdeja mielenterveysproblematiikan ymmärtämiseen. Vertaisen katsottiin pääsevän henkilökohtaisemmalle tasolle asiakkaan kanssa kuin ammattiauttajan. Omakohtaisen toipumiskokemuksen koettiin kannustavan toisia asiakkaita, auttavan sitoutumisessa ja tukevan toipumisprosessia. Päihdejärjestöissä asiakkaat saivat vertaisilta myös näkökulmaa päihteettömään elämään.

"Vertaisten tuki on joillekin se suurin ja tärkein toipumisen kannalta." (Työntekijä 4.)

Vertaisten kokemuksesta katsottiin olevan hyötyä työn, työtapojen, hoidon ja palvelujen suunnittelemisessa, arvioimisessa ja kehittämisessä entistä asiakaslähtöisemmiksi ja monipuolisemmiksi. Vertaiset voivat lisätä työn ihmisläheisyyttä ja merkityksellisyyttä sekä tuoda asioihin uutta näkökulmaa ja konkreettista apua. Vertaisten on mahdollista nostaa esiin työn epäkohtia, sillä heillä on tietoa asiakkaiden toiveista. Vertaistukea ei myöskään voi korvata ammatillisella osaamisella.

"Kun toteutamme kuntoutuksen ja sotepalveluiden yhteiskehittämistä -- [vertaisten] rooli on keskeinen, niin ammattilaisten uudenlaisen työotteen kuin kuntoutujien osallistumisen kannalta." (Työntekijä 5.)

Työntekijät eivät löytäneet vertaistoiminnasta juurikaan haittoja tai riskejä. Haasteeksi nähtiin toiminnan perustuminen vertaisen persoonaan ja henkilökohtaisiin ominaisuuksiin. Esimerkiksi mahdollisuus ottaa ammattilaisen rooli, ilman ammatillista koulutusta, voi vaikeuttaa hoito-ohjelman toimivuutta.

\section{Vertaistoimintaan osallistumisen motiivit}

Vertaisille itselleen keskeisintä toiminnassa oli mahdollisuus auttaa toisia. Se näkyi haluna jakaa kokemustietoa ja tukea toisia samassa elämäntilanteessa olevia esimerkiksi kertomalla omista selviytymiskeinoista. Vertaisen tarina voi olla peili, johon kuntoutuja voi verrata omia kokemuksiaan.

\section{"Haluan luoda toivoa ja auttaa toisia oman} kokemukseni kautta." (Vertainen 2.)

Auttamisen halu perustui vertaisen omaan selviämiseen, sairauden aikana koettuun avuttomuuteen ja itse saatuun vertaistukeen tai apuun vaikeassa tilanteessa. Vertaista motivoi siis halu antaa jotain takaisin niin, että joku toinen voi saada voimaa selviämiseen.

"Haluan olla tukena muille niin kuin minua on tuettu kun olen tarvinnut apua." (Vertainen 3.)

Toiminnan motiivina voivat olla myös päinvastaiset kokemukset, jolloin vertainen haluaa antaa toisille tukea, jota ei itse aikanaan saanut. Hän voi myös toivoa voivansa toimia toisten asiakkaiden äänenä tai vaikuttaa laajemmin.

"Haluan, että jatkossa olisi apua sellaisissa asioissa, joihin apua ei ollut silloin, kun olisin itse sitä kipeästi tarvinnut." (Vertainen 4.)

Omat sekä hyvät että huonot kokemukset ja auttamisen halu liittyivät myös tarpeeseen kehittää palveluja. Vertaiset halusivat olla mukana luomassa uusia toimintatapoja ja hoitokäytäntöjä, jotka vastaisivat paremmin asiakkaiden tarpeita. Tämä tarkoitti omien elämänkokemusten ja toipumista edistäneiden sekä sitä vaikeuttaneiden asioiden tuomista julkisiksi tai ammattilaisten ja opiskelijoiden tietoisuuteen.

"Oman raitistumisen myötä syntyi halu auttaa muita saamaan apua. Kehittä- 
mään palveluita paremmiksi, jotta niistä olisi enemmän apua ja että sitä olisi helpompi saada." (Vertainen 5.)

Auttamisessa näkyi vertaistuen vastavuoroisuus sekä sen kautta tuleva mahdollisuus kääntää omat vaikeat kokemukset voimavaraksi.

"Auttamalla toisia autamme myös itseämme." (Vertainen 6.)

Tärkeitä tekijöitä olivat sisäiset ja omakohtaiset syyt. Vertaistoiminta tuki vertaisen omaa kuntoutumista, raittiutta, toipumista tai mielenterveyttä. Se oli terapeuttista ja eheyttävää, paransi vointia, antoi mielekästä tekemistä ja toi elämään sisältöä. Merkityksellistä oli saada positiivista palautetta. Toimintaan osallistuminen loi tunteen siitä, että on tarpeellinen; sen kautta voi määritellä itsensä yhteiskunnan hyödylliseksi jäseneksi.

"Haluan olla hyödyllinen ja aktiivinen yhteisön ja yhteiskunnan jäsen.” (Vertainen 7.)

"Koen työn tärkeäksi ja saan siitä itse onnistumisen kokemuksia. Menneisyyden asioista avoimesti puhuminen auttaa myös itseäni, joten teen työtä myös hyvin itsekkäistä syistä." (Vertainen 8.)

Vastauksissa nousi esiin vertaistoiminnan hyödyllisyys itselle. Toiminta voi olla harrastus, palkkatyön korvike, vastine työlle tai liittyä omaan osaamisalaan. Sen kautta sai uusia ystäviä ja tekemistä vapaa-aikaan. Joillain vastaajilla tavoitteet suuntautuivat tulevaisuuteen, kuten mahdollisuuteen saada opintoihin vaadittavaa kokemusta tai työpaikka.

"Toivon tehtävän auttavan minua saamaan järjestöalalta työkokemusta ja mahdollisesti työpaikan." (Vertainen 9.)

Osalla vastaajista vertaistoimintaan osallistumisen taustalta löytyi yhteiskunnallinen orientaatio, jolloin heitä motivoi halu yhteis- kunnalliseen vaikuttamiseen tai mahdollisuus arvojen toteuttamiseen. Toiminnan tavoitteena oli päihde- ja mielenterveysongelmiin liittyvien ennakkoluulojen ja stigman vähentäminen esimerkiksi arkipäiväistämällä mielenterveyteen ja päihdeongelmiin liittyviä asioita, oman ryhmän yhteiskunnallisen aseman parantaminen sekä asenteisiin, koulutukseen ja hoitoon vaikuttaminen.

\section{"Lisäksi arvomaailmani on muuttunut te- rapian ja toipumisen myötä siten, että ha- luan auttaa yhteiskunnan epäkohdista kär- siviä - jos ei muuten, niin nostan näi- tä epäkohtia ssuuren yleisön tietouteen ja tarkasteltavaksi." (Vertainen 10.)}

Vertaistoiminta koettiin kutsumustehtäväksi, joka on tarpeellista, palkitsevaa ja antoisaa, vaikka vie voimia. Se oli keino saada hyvä kiertämään.

"Ihan on mun kutsumus juttu!" (Vertainen 11.)

\section{Vertaisten tukeminen järjestöissä - tuen tarve ja tukitoimenpiteet}

Vertaistukitoiminnassa ollaan tekemisissä monimutkaisten ilmiöiden ja ihmissuhteiden kanssa, joten vertaiset tarvitsevat tukea. Antamalla tukea voidaan varmistaa toimintaan sitoutuminen, virkistäytyminen, tehtävien mielekkyyden säilyminen ja kasvu vertaisena sekä vähentää uupumisen riskiä. (Ks. Myllymaa $2010,87$.$) Seuraavaksi tarkastelemme vertais-$ ten kokemaa uupumista ja väsymistä sekä järjestöissä käytettyjä tukitoimia.

Vertaisilta kysyttiin, olivatko he joskus uupuneet tai väsyneet liikaa toimiessaan vertaisina (vastausvaihtoehdot: ei/kyllä, kuka huomasi, saitko apua ja mistä?). Joka kolmas vertaisista oli kokenut uupumusta tai väsymystä vertaistoiminnassa. Tunteet korreloivat merkitsevästi vertaisten kokemukseen siitä, että järjestö tuntui odottavan heiltä liikaa $(R=0,24$, $\mathrm{p}=0,030)$. Tosin vain joka kymmenes vastaajista koki järjestön odotukset liiallisiksi.

Noin 80 prosenttia aineiston vertaisista il- 


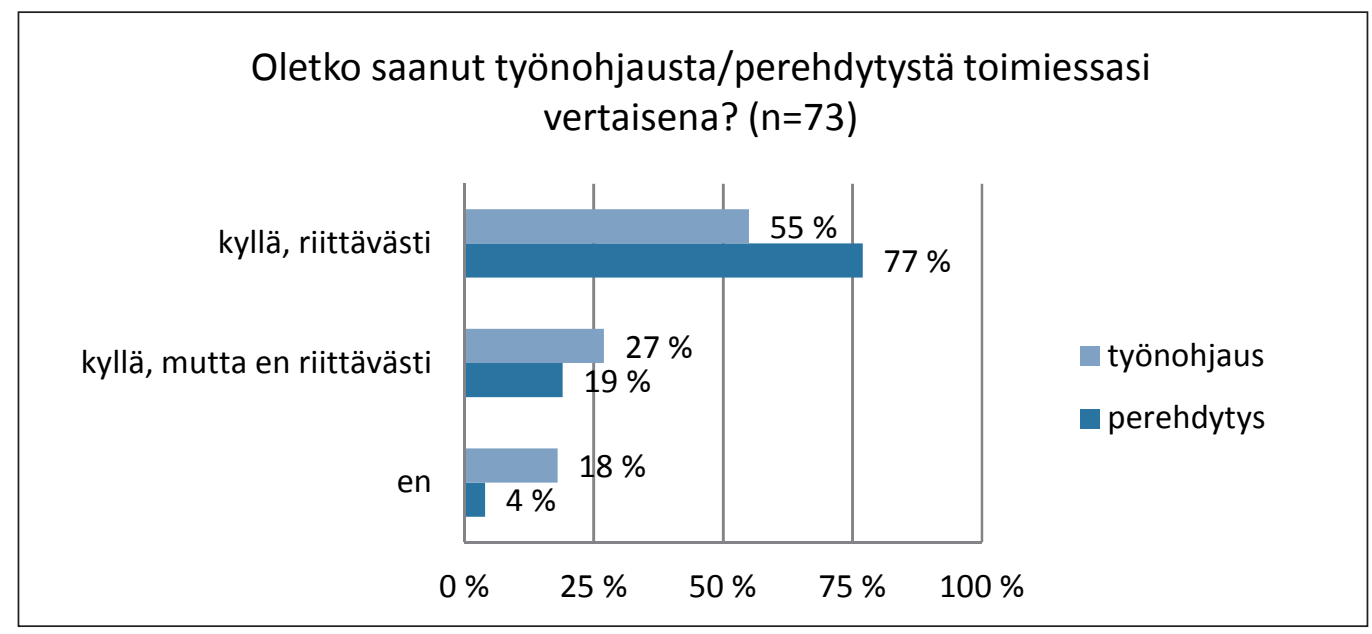

Kuvio 1. Vertaisten kokemukset työnohjauksen ja perehdytyksen saannista ja riittävyydestä.

moitti saaneensa työnohjausta. Perehdytystä tehtäviinsä vertaisena oli saanut vielä useampi vastaajista, peräti 96 prosenttia. Toisaalta reilu neljännes vastaajista oli kokenut saamansa työnohjauksen riittämättömäksi, viidennes saamansa perehdytyksen (kuvio 1). Vajaa viidennes vastanneista ei ollut saanut työnohjausta lainkaan. Riittävä työnohjaus $(\mathrm{R}=-0,34, \mathrm{p}=0,050)$ ja perehdytys $(\mathrm{R}=-0,21$, $\mathrm{p}=0,070)$ olivat yhteydessä vähäisempiin uupumisen ja väsymisen kokemuksiin. Vertaistoiminnan kyselyn avovastaukset vahvistivat osaltaan työnohjauksen merkitystä vertaisten jaksamisen tukemisessa:

"Ei kukaan huomannut, mutta itse tunnen väsymyksen. Onneksi on ollut työnohjausta. Ilman sitä olisi ollut vaikeaa ja en olisi saanut ryhmänohjauksessa tarvitsemiani työkaluja ongelmatilanteisiin." (Vertainen 12.)

Vastaajat kuvasivat järjestössään käytössä olevia, vertaisiin kohdennettuja tukitoimenpiteitä. Joissain järjestöissä vertaisille oli nimetty oma tukihenkilö tai yhteyshenkilö tai heitä varten oli palkattu työntekijä. Erilaiset keskustelukäytännöt (kehitys- ja yksilökeskustelut, esimiehen kanssa käytävät keskustelut) joko säännönmukaisesti tai tarvittaessa olivat yleisiä.
"Keskustelut joissa huomioidaan heidän hyvinvointi, kattavat keskustelut n. 2-3 kertaa/kk." (Työntekijä 6.)

Keskustelumahdollisuuksien lisäksi vertaisille järjestettiin säännöllisiä tapaamisia, palavereja tai omia ryhmiä sekä annettiin työhön liittyvää tukea, kuten purkutilaisuus ryhmän jälkeen. Keskeisiä olivat myös erilaiset työn ja vastuun jakamisen menetelmät, kuten vuorotteleminen tai se, ettei vertaiselle sälytetä liikaa vastuuta ryhmätoiminnoista.

On huomioitava se, että vertainen ei välttämättä rohkene tai halua ottaa väsymystään puheeksi itse. Vertaisten tukemisessa erityisen tärkeäksi nousikin jatkuva toiminnan seuranta ja arviointi, jota käydään keskustellen tai systemaattisesti työmäärää seuraten. Kommunikaatiossa tärkeäksi nousi pyrkimys avoimuuteen ja välittömyyteen sekä jatkuvaan vuoropuheluun.

"Itse olen huomannut pientä uupumista. Olen harkinnut taukoa vertaisena toimimiseen, mutta en ole sitä vielä tohtinut ehdottaa. (Vertainen 13.)

"Työmäärää seurataan vertaisten palauttamien lomakkeiden (keitä ovat tukeneet ja mitä tehneet) avulla sekä pitämällä yllä ryhmissä jatkuvaa keskustelua oman hyvinvoinnin tärkeydestä. Jos mitään uupu- 
misen merkkejä on ilmassa, niihin tartutaan ja puututaan hyvin matalalla kynnyksellä.” (Työntekijä 1.)

Vastauksissa näkyi myös vertaisuuteen kuuluvat molemminpuolisuus ja vastavuoroisuus: toiset vertaiset saattoivat ottaa enemmän vastuuta, kun huomasivat jonkun uupuvan.

"Huomasin auttaneeni, myöhemmin hyvä mieli. Ja huonona päivänä sama ihminen tuki minua." (Vertainen 6.)

Vertaisten uupumukseen oli saatu apua myös ammattiauttajilta, ohjaajilta tai järjestön ammattilaisilta. Puhuminen tai työnohjaus voi auttaa itsessään, toisaalta työntekijät voivat tarvittaessa määrätä vertaisen lepäämään. Yksittäisiä mainintoja tukimenetelmistä saivat konsultaatio, ohjausryhmä, koulutukset, virkistystilaisuudet, yhteistyö paikallisten yhdistysten kanssa koulutuksen ja työnohjauksen tiimoilta sekä mahdollisuus osallistua toiminnan arviointiin, suunnitteluun ja kehittämiseen.

\section{Johtopäätökset ja pohdinta}

Tutkimuksessa hyödynnettiin kahta aineistoa, mikä mahdollisti vertaistoiminnan tarkastelun organisaatiotasolla ja vertaisten näkökulmasta. Aineistoja yhdistämällä saatiin tietoa vertaistoiminnan yleisyydestä päihde- ja mielenterveysjärjestökentällä ja erilaisissa toimintaympäristöissä sekä vertaisuuteen liittyvistä käytännöistä. Tutkimuksessa onnistuttiin käyttämään moniaineistollisuutta niin, että siinä pystyttiin tuottamaan uutta ja merkityksellistä tietoa vertaistoiminnasta. Katsomme, että tutkimusaineisto vastasi tutkimuskysymyksiin hyvin aineiston heikkouksista huolimatta. Vertaistoiminnan kyselyn vastaajamäärät olivat suhteellisen pieniä, katoanalyysiä ei voitu tehdä ja kyselyssä käytetyt mittarit olivat karkeita. Tutkimuksen luotettavuutta lisäsi kuitenkin se, että vertaistoiminnan kyselyn laatimiseen osallistuneet vertaiset ohjasivat kyselyn sisältöä. Lisäksi tutkimus rajautui hankejärjestöihin ja niiden paikallisyhdistyksiin, joten tuloksia ei voi yleistää koskemaan koko päihde- ja mielenterveysjärjestökenttää.

Tulokset vahvistavat käsitystä vertaisuuden vakiintuneesta asemasta päihde- ja mielenterveysjärjestöjen toiminnassa (vrt. Hietala-Paalasmaa \&t Vuorela 2004, 35-36; Kaskela ym. 2014). Keskeistä oli vertaisten omakohtaisten kokemusten ja sen tuoman ymmärryksen merkitys asiakkaille sekä muille kuntoutujille (vrt. Arminen 1998, 11; Nylund 1996, 194; Hietala 2013, 294). Vertaisuuden katsottiin luovan luottamusta ja uskottavuutta yhdistyksen toimintaan, mikä helpottaa esimerkiksi marginaalissa elävien ihmisten tavoittamista. Työtekijät tunnistivat vertaisuuden merkityksen myös oman työnsä kehittämisessä.

Tutkimuksen tuloksissa konkretisoituivat aiemmissa tutkimuksissa laaditut vertaisuuden määritelmät ja ominaisuudet, kuten vastavuoroinen tukeminen (vrt. Koskisuu \&t Narumo 2004, 19; Muurinaho 2001, 16) sekä sosiaalisuuden, vuorovaikutuksen ja yhteisöön kuulumisen merkitykset (vrt. Laimio \&t Karnell 2010, 9; Mikkonen 2009). Toiminta antaa vertaisille mahdollisuuden auttaa toisia omakohtaisen kokemustiedon pohjalta sekä toteuttaa omia arvoja ja yhteiskunnallista orientaatiota. Vertaisena toimiminen myös tukee kuntoutujan tai toipujan omaa hyvinvointia. Vertaistoiminnassa korostui myös toiminnasta saatava konkreettinen hyöty. Osallistumisen motiivit liittyvät vertaisten arkeen, työhön ja vapaaaikaan.

Keskeiseksi havainnoksi ja tulokseksi nousee työntekijöiden ja vertaisten näkemysten erilaisuus. He painottivat vertaisten tehtävien eri osa-alueita. Työntekijät korostivat vertaisten roolia järjestön sisällä auttamis- ja tukitehtävissä eli henkilökohtaisen tuen tarjoamista (vrt. Rissanen 2015). Vertaiset itse toivat voimakkaammin esiin välillistä auttamista (vrt. Rissanen 2015) eli kehittämis- ja vaikuttamistoimintaan osallistumista sekä roolia kouluttajina, luennoitsijoina ja panelisteina eli toimimista myös järjestön ulkosuhteissa. Kyselyn tulosta tukee kahdessa mielenterveyspalveluja tarjoavassa yksikössä tehty tutkimus, jossa todettiin, että suuri osa työntekijöistä ja palvelun käyttäjistä toivoi yhteistyön lisäämistä, mutta tavat ja perusteet olivat erilaisia. Pal- 
velun käyttäjät tai vertaiset toivoivat vaikutusvaltansa kasvattamista ja mahdollisuutta muuttaa toimintatapoja. Työntekijät painottivat osallistumista ja halusivat lisätä konsultaatiokäytäntöjä, eivät niinkään tasavertaista yhteistyötä. (Rutter ym. 2004, 1982.) Tulos korostaa tarvetta huomioida vertaisten oma orientaatio toiminnan sisältöjen ja tavoitteiden suunnittelussa. Palveluiden kehittäminen asiakaslähtöisempään suuntaan nousi keskeiseksi vertaisten tehtäväksi sekä työntekijöiden että vertaisten itsensä näkökulmasta.

Joka kolmas tutkimukseen osallistuneista vertaisista oli kokenut tehtävässään uupumusta tai väsymystä. Tutkimukseen osallistuneiden vertaisten joukko oli pieni, joten tulosta ei voi yleistää laajasti. Jatkossa vertaisten jaksamista ja hyvinvointia tulisi tarkastella monipuolisemmilla ja tarkemmilla mittareilla kuin kyselyssä. Voidaan kuitenkin todeta, että järjestöissä on tärkeää panostaa vertaisten työnohjaukseen, tukemiseen ja toimiin, joilla vertainen voi tarvittaessa helpottaa työmääräänsä tai vetäytyä tehtävistään. Järjestöissä olikin huomioitu vertaisten tukeminen erilaisin keinoin.

Vertaistoimintaa tarjotaan enemmän suurilla toiminta-alueilla toimivissa päihde- ja mielenterveysyhdistyksissä (vrt. Ala-Nikkola ym. 2016). Laaja väestöpohja mahdollistaa monipuoliset vertaisuuden viiteryhmät ja suurilla paikkakunnilla päihde- ja mielenterveysongelmiin liittyvä stigma on helpompi välttää kuin pienissä yhteisöissä. Se alentanee kynnystä osallistua yhdistysten toimintaan. Olisi tärkeä mahdollistaa vertaistoiminta myös pienillä, syrjäisemmillä paikkakunnilla. Haasteeseen oli tartuttu etenkin valtakunnallisissa järjestöissä, joista kolmanneksen toimintatapoihin kuului internet-välitteinen vertaisuus. Vertaisuuden merkitys painottui ennen vuotta 1986 perustettujen yhdistysten toiminnassa. Jatkotutkimuksissa olisikin kiinnostavaa tarkastella, vastaavatko nuoremmat yhdistykset enemmän muihin nyky-yhteiskunnan muuttuneisiin tarpeisiin (esimerkiksi kehittämistoiminta, palvelutuotanto) ja mihin suuntaan vertaistoiminnan merkitys järjestöissä kehittyy.
Tulosten merkitys: Järjestöjen vertaistoiminnassa on tärkeää ottaa huomioon se, että työntekijöiden ja vertaisten käsitykset toiminnan tavoitteista ja luonteesta voivat olla erilaisia. Toisaalta esimerkiksi perehdytys ja työnohjaus ovat tärkeitä menetelmiä, kun tuetaan vertaisten jaksamista. On tärkeää järjestää yhteisiä tilaisuuksia, joissa vertaiset ja työntekijät voivat keskustella vertaistoiminnasta, sen tavoitteista ja vertaisten jaksamisesta.

\section{Tiivistelmä}

Artikkelissa tarkastellaan vertaistoimintaa päihde- ja mielenterveysjärjestöissä. Tutkimusaineisto koostuu kahdesta kyselystä. Ensimmäisessä kartoitettiin paikallisten päihde- ja mielenterveysyhdistysten $(n=187)$ ja valtakunnallisten järjestöjen ( $n=28)$ johtajien käsityksiä vertaisuuden merkityksestä niiden toiminnassa sekä niissä tuotettavia vertaistoiminnan muotoja. Täydentävää aineistoa kerättiin järjestöjen työntekijöille ( $n=61)$ ja vertaisille $(n=75)$ kohdistetulla kyselyllä, jossa tarkasteltiin vertaistoiminnan merkitystä, siihen liittyviä tehtäviä, vertaisten roolia ja asemaa sekä heihin kohdistuvia tukitoimenpiteitä ja tuen tarvetta.

Vertaistoiminnalla oli keskeinen merkitys päihde- ja mielenterveysjärjestökentällä. Sen painoarvo kuitenkin vaihteli. Vertaistoiminnan merkitys oli suurempi ja siihen liittyviä toimintamuotoja oli enemmän suurilla toiminta-alueilla toimivissa yhdistyksissä. Sen painoarvo korostui etenkin ennen vuotta 1986 perustetuissa yhdistyksissä.

Vertaisten rooli ja tehtävät hahmottuivat hieman eri tavoin työntekijöiden ja vertaisten itsensä näkökulmasta. 
Työntekijät korostivat vertaisten roolia järjestöjen asiakastyössä ja konkreettisessa auttamis- ja tukitoiminnassa, kun taas vertaiset itse näkivät roolinsa laajemmin myös järjestön ulkosuhteissa ja yhteiskunnallisina vaikuttajina. Aineiston vertaisista kolmannes oli kokenut uupumusta tai väsymystä toimiessaan vertaisena. Järjestöissä on tärkeää taata sekä vertaisten oman orientaation huomioiminen toiminnan suunnittelussa ja kehittämisessä että tarvittavat resurssit vertaisten tukemiseen.

Avainsanat: vertaistuki, vertaistoiminta, päihdejärjestöt, mielenterveysjärjestöt

\section{English summary}

The forms and importance of peer support in substance abuse and mental health organizations

The study examines peer support in substance abuse and mental health organizations. The study is based on two sets of data. Information on the importance and forms of peer support provided was collected by a questionnaire sent to local $(n=187)$ and national $(\mathrm{n}=28)$ non-governmental organizations in the fields of substance abuse and mental health, addressed to the CEO or chairman of the board. Supplementary data on the roles and tasks of peers as well as their need for support in their own work was collected by a questionnaire sent to the personnel $(n=61)$ and peers $(n=75)$ in these organizations.

Peer support had a central role in both substance abuse and mental health organizations but it differed in different kinds of organizations. Peer support had a stronger emphasis and was more common in organizations operating in larger cities. Al- so, organizations founded especially before year 1986 had a stronger element of peer support in them compared to younger organizations. The peers' roles and tasks were perceived somewhat differently by the personnel and the peers themselves. The personnel emphasized the peers' role in the organization's customer work and practical help and support related tasks, whereas the peers themselves perceived their role more broadly, including in the organizations' external relations and in advocacy work. Every third of the peers who answered the questionnaire had experienced fatigue or exhaustion in their work as a peer. The results highlight the need to consider the peer workers' own orientation and expectations in planning peer support in substance and mental health organizations, as well as the need to provide sufficient resources for supporting the peers' well-being and coping skills in their work.

Keywords: peer, peer support, NGO, substance abuse organizations, mental health organizations

Authors:

Päivi Rissanen, PhD, researcher, Finnish

Central Association for Mental Health

Sari Jurvansuu, M.Soc.Sc, researcher, Finnish Association for Substance Abuse Prevention

Päivi Rissanen, VTT, tutkija, Mielenterveyden keskusliitto

Sari Jurvansuu, YTM, tutkija, Ehkäisevä päihdetyö EHYT ry

\section{Lähteet}

Ala-Nikkola T, Sadeniemi M, Kaila M, Saarni S, Kontio R, Pirkola S, Joffe G, Oranta 0, Wahlbeck K (2016) How size matters: exploring the association between quality of mental health services and catchment area size. BMC Psychiatry 16, 289. http://bmcpsychiatry.biomedcentral.com/articles/10.1186/s12888-016-0992-5\#Sec2 (haettu 16.12.2016) 
Arminen I (1998) Therapeutic Interaction: A Study of Mutual Help in the Meetings of Alcoholics Anonymous. Akateeminen väitöskirja. The Finnish Foundation for Alcohol Studies 45, Helsinki.

Campbell P (1996) The history of the user movement in the United Kingdom. Teoksessa Heller T, Reynolds J, Gomm R, Muston R, Pattison S (toim.) Mental Health Matters. Macmillan, Basingstoke, 218-225.

Davidson L, Chinman M, Kloos B, Weingarten R, Stayner D, Tebes, J K (1999) Peer Support Among Individuals With Severe Mental Illness: A Review of the Evidence. Clinical Psychology: Science and Practice 6, 2, 165-187.

Hietala 0 (2013) A-klinikan asiakaskahvilassa: etnografinen tutkimus asiakkaiden juomiselle ja ammattiavulle antamista merkityksistä. Akateeminen väitöskirja. Diakonia-ammattikorkeakoulun julkaisuja A. Tutkimuksia 37. Helsinki.

Hietala-Paalasmaa 0, Vuorela M (2004) Työtoiminnasta tukea kuntoutumiseen ja osallisuuden oikeutta. Kuntoutus 27, 3, 29-41.

Hokkanen L (2014) Autetuksi tuleminen: Valtaistavan sosiaalisen asianajon edellyttämät toimijuudet. Akateeminen väitöskirja. Acta Universitatis Lapponiensis 278. Lapin yliopisto, Rovaniemi.

Huuskonen P (2015) Vertaistuki. Vammaispalvelujen käsikirja. https://www.thl.fi/fi/web/vammaispalvelujen-kasikirja/itsenaisen-elaman-tuki/vertaistuki (haettu 11.8.2016)

Kangas I (2003) Sairaan asiantuntijuus - tieto ja kokemus sairastamisen arjessa. Teoksessa Honkasalo M-L, Kangas I, Seppälä U (toim.) Sairas, potilas, omainen: Näkökulmia sairauden kokemiseen. Tietolipas 189. Suomalaisen Kirjallisuuden Seura, Helsinki, 73-95.

Kaskela T, Pitkänen T, Tourunen J, Valkonen J, Härkönen J, Suvisaari J, Wahlbeck K, Kaikkonen R (2014) Järjestö- ja harrastustoimintaan osallistuminen ja päihde- ja mielenterveysongelmat - ATH-tutkimuksen tuloksia. Teoksessa Jalava J ym. ATHtutkimuksen tuloksia - Järjestökentän tutkimusohjelma. Työpaperi 37/2014. Terveyden ja hyvinvoinnin laitos, Helsinki, 21-28.

Koskisuu J, Narumo R (2004) Kokemusasiantuntijuuden hyödyntäminen mielenterveyskuntoutuksessa. Kuntoutus 27, 3, 17-23.

Kulmala A (2004) Toiset identiteettiä rakentamassa. Yhteiskuntapolitiikka 69, 3, 231-241.

Laimio A, Karnell S (2010) Vertaistoiminta - kokemuksellista vuorovaikutusta. Teoksessa Vertaistoiminta kannattaa. Aspa-säätiö, Helsinki, 9-19.

Lehtinen S-T (1997) Vapaaehtoistoiminta - kasvava voimavara? Näkökulmia ammattityöhön. Omaehtoisen kehityksen julkaisuja. Sarja B. Vapaaehtois- toiminta, 1. Kansalaisareena ry, Helsinki.

Leppo A, Perälä R (2015) Väsynyt vertainen tee-seitse-hyvinvointivaltiossa. Abstraktikirja.

Mikkonen I (1996) Sairastuneiden vertaisryhmät ja terveydenhuollon ammattilaiset. Teoksessa Matthies A-L, Kotakari U, Nylund M (toim.) Välittävät verkostot. Vastapaino, Tampere, 217-225.

Mikkonen I (2009) Sairastuneen vertaistuki. Akateeminen väitöskirja. Kuopion yliopiston julkaisuja E, Yhteiskuntatieteet, no 173.

Muurinaho J (2001) Mielenterveyskuntoutujien omaapuryhmät. Kuntoutus 24, 2, 8-17.

Myllymaa T (2010) Vertaistoimijoiden jaksaminen ja työn tuki. Teoksessa Vertaistoiminta kannattaa. Asumispalvelusäätiö Aspa, Helsinki, 87-93.

Nylund M (1996) Suomalaisia oma-apuryhmiä. Teoksessa Matthies A-L, Kotakari U, Nylund M (toim.) Välittävät verkostot. Vastapaino, Tampere, 193205.

Nylund M (1999) Oma-apuryhmät välittäjinä arjessa. Teoksessa Hokkanen L, Kinnunen P, Siisiäinen M (toim.) Haastava kolmas sektori: Pohdintoja tutkimuksen ja toiminnan moninaisuudesta. Sosiaalija terveysturvan keskusliitto ry, Helsinki, 116-134.

Rajala J (2008) Selvästi parempi: A-kiltojen liitto 40 vuotta 1968-2008. A-kiltojen liitto, Helsinki.

Rissanen P (2015) Toivoton tapaus? Autoetnografia sairastumisesta ja kuntoutumisesta. Akateeminen väitöskirja. Kuntoutussäätiön tutkimuksia 88/2015. Kuntoutussäätiö, Helsinki.

Rutter D, Manley C, Weaver T, Crawford M, Fulop N (2004) Patients or partners? Case studies of user involvement in the planning and delivery of adult mental health services in London. Social Science \& Medicine 58, 1973-1984.

Savukoski M (2008) Vapaaksi anoreksian kahleista: Narratiivinen tutkimus selviytymispoluista. Akateeminen väitöskirja. Acta Universitatis Lapponiensis 142. Lapin yliopisto, Rovaniemi.

Siltaniemi A, Hakkarainen T, Luhtanen M, Perälahti A, Särkelä R, Londen P (2011) Kansalaisbarometri: Hyvinvointi, palvelut ja osallisuus mielipiteissä. Sosiaali- ja terveysturvan keskusliitto ry, Helsinki.

STM (2012) Mielenterveys- ja päihdesuunnitelma: Ehdotukset mielenterveys- ja päihdetyön kehittämiseksi vuoteen 2015: Väliarviointi ja toteutumisen kannalta erityisesti tehostettavat toimet. Sosiaali- ja terveysministeriön julkaisuja 24. Sosiaali- ja terveysministeriö, Helsinki.

Vuorinen M, Helasti K (1997) Juttukeppi kiertämään kokemuksia oma-aputoiminnasta vuosilta 19941997. Mielenterveyden keskusliitto, Helsinki. 